\title{
Un breve homenaje al Dr. Carlos A. Gianantonio a los 25 años de su fallecimiento
}

A brief tribute to Dr. Carlos A. Gianantonio 25 years after his death

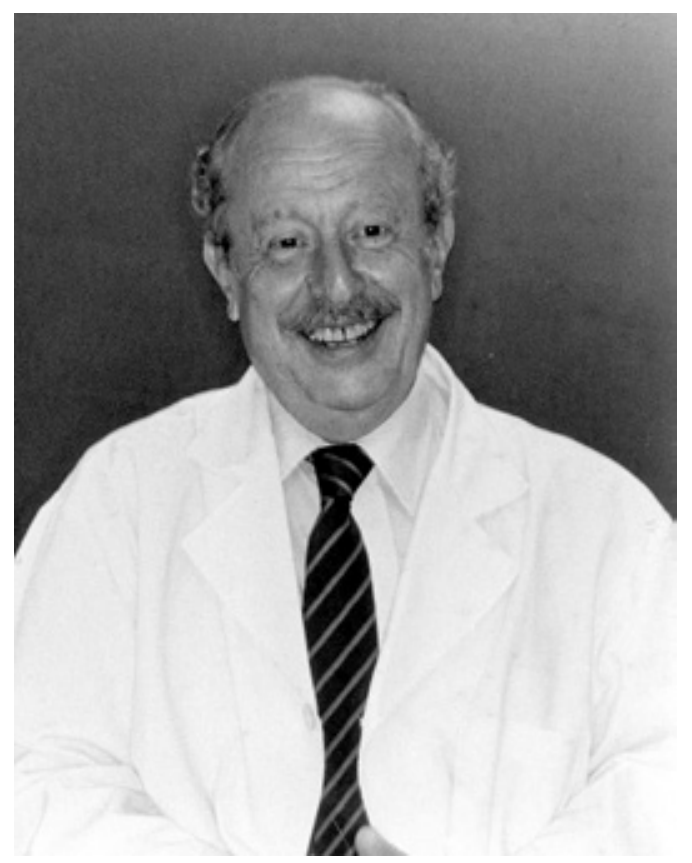

Ha pasado bastante tiempo que nuestro maestro se ha ido por siempre, pero está con nosotros permanentemente, y puedo decir que todos los días nos acompaña.

Entre las muchísimas lecciones que nos dio, se podría destacar cuando nos enseñaba, y solía insistir siempre, cómo teníamos que comportarnos cuando estábamos con los pacientes, tanto con los niños, como los padres, y con alegría.

Él fue una excepcional persona, en todos los puntos que pueden tener los seres humanos. Frecuentemente nos fue enseñando la enorme importancia que tenían los aspectos de la ética en la práctica médica, y nos decía que esos debían estar presentes en todo momento, y de esa forma podíamos mantener el humanismo, que, con la ciencia, son las dos columnas de la medicina.

Asimismo, fue realmente un sabio, al enseñarnos cómo debíamos aprender la ciencia que abordaba la pediatría, y en estas palabras, nos dijo todo: "Los pediatras tenemos labores que cumplir cerca de las familias argentinas, repitiendo una y otra vez los gestos esenciales de nuestra profesión; ayudar, acompañar, consolar, curar tal vez..."

De esta forma, el siempre maestro aún lo seguimos teniendo entre nosotros.

José M. Ceriani Cernadas Editor en Jefe 